\title{
KEUNTUNGAN INVESTASI DI SAHAM SYARIAH
}

\author{
${ }^{1}$ Fadlilatul Ulya, ${ }^{2}$ Via Sukmaningati
}

\begin{abstract}
ABSTRAK
Penelitian ini bertujuan untuk mendiskripsikan keuntungan dalam berinvestasi di saham syariah. Penelitian ini menggunakan pendekatan kualitatif dengan metode deskriptif analitis. Populasi dalam penelitian ini adalah para investor saham syariah di Indonesia. Sampelnya adalah 10 investor saham syariah. Sumber data yang digunakan adalah data primer didapatkan dari 10 responden yang memiliki saham syariah dan mengisi kuisioner terbuka pada google form, sedangkan data sekunder yang ada diperoleh dengan mencari informasi dari beberapa literatur dan artikel yang berkaitan. Teknik pengumpulan datanya melalui kuisioner terbuka dan studi pustaka. Hasil dari penelitian ini menunjukkan bahwa banyak keuntungan yang didapatkan oleh investor saham syariah, yaitu investasi saham syariah sesuai dengan ajaran agama Islam, capital gain, dividen, terdapat saham likuid dan masuk Indeks LQ45, terdapat saham Blue-chip dan kepemilikan perusahaan.
\end{abstract}

Kata Kunci : Keuntungan, Investasi, Saham Syariah

\section{A. PENDAHULUAN}

Pasar keuangan (Financial Market) mempunyai peranan penting dalam perekonomian suatu negara, karena dapat mempertemukan antara pihak yang memiliki kelebihan dana dengan pihak yang membutuhkan dana. Tanpa adanya financial market, maka peminjam uang (kreditur) akan mengalami kesulitan dalam menemukan debitur yang bersedia untuk memberikan pinjaman kepadanya. Financial market dapat dibagi menjadi dua, yakni pasar uang (Money Market), dan pasar modal (Capital Market). Pasar uang merupakan pertemuan antara permintaan dan penawaran dana jangka pendek. Sedangkan pasar modal memperjualbelikan efek (surat berharga atau securities) seperti saham, obligasi, derivatif, dan reksa dana (mutual funds) (Hermuningsih, 2012).

Salah satu instrumen pasar keuangan di pasar modal adalah saham (stock). Seiring dengan perkembangan investasi saham di Indonesia, maka Pasar Modal Indonesia juga selalu mengalami pembaharuan. Pada awalnya hanya terdapat satu jenis pasar modal di Indonesia, karena perkembangan sistem ekonomi syariah yang menunjukkan pertumbuhan yang bagus menjadi tonggak munculnya instrumen saham syariah pada pasar modal Indonesia. Pasar Modal syariah di Indonesia dimulai sejak tahun 2017, diawali dengan lahirnya Reksa Dana Syariah yang diprakarsai Dana Reksa Investment Management pada 3 Juli 1997. Selanjutnya Bursa Efek Indonesia meluncurkan Jakarta Islamic index (JII) dengan tujuan untuk memberikan pilihan kepada para investor yang tertarik menanamkan modal secara syariah.

Meskipun pertumbuhan pasar modal syariah cukup menggembirakan, namun ekspos pasar modal syariah masih minim. Kurangnya pemahaman masyarakat

${ }^{2}$ IAIN, Kudus, fadlilatul.ulya10@gmail.com 
mengenai pasar modal syariah menjadi keraguan bagi investor untuk menanamkan modalnya pada pasar modal. Hal ini dikarenakan adanya praktik kegiatan di pasar modal yang mengandung unsur spekulasi. Selain itu, sebagian besar masyarakat seringkali masih beranggapan bahwa saham mengandung unsur riba, maysir, dan gharar, karena tidak ada kepastian yang jelas. Oleh karena itu, dibutuhkan pengetahuan mengenai pasar modal syariah, baik dari konsep dan prinsip, serta mekanisme perdagangannya (Nurlita, 2014).

Beberapa penelitian yang telah dilakukan terkait dengan saham syariah seperti yang dilakukan oleh (Faqih, 2018) menjelaskan bahwa dari sudut pandang hukum Islam, mekanisme jual beli saham syariah adalah sistem jual beli yang berkesinambungan dan dilakukan dalam satu majelis (bai' al-musawamah). Dengan mekanisme tersebut, hak dari masingmasing pihak yang terlibat di dalamnya dapat dijaga pemenuhannya. Sementara dalam praktiknya, menerapkan akad wakalah dengan bertindak sebagai perusahaan pialang saham yang mewakili (wakil) kepentingan nasabah baik untuk menjual atau membeli saham dari para pemegang saham (muwakil). Kemudian penelitian yang dilakukan oleh (Kasanah \& Worokinasih, 2018), tidak ada perbedaan yang signifikan antara return dan risk saham syariah yang berada di Jakarta Islamic Index dengan return saham konvensional yang berada pada Indeks IDX30 periode 2014-2016. Sedangkan hasil dari penelitian (Febrianti, 2018), terdapat perbedaan signifikan antara kinerja indeks harga saham konvensional dengan kinerja indeks harga saham syariah dilihat selama periode tahun 2015-2017.

Berdasarkan latar belakang di atas, peneliti bermaksud mengkaji lebih lanjut tentang apa itu saham syariah dan apa saja keuntungannya dengan menggunakan data yang ada dari seluruh saham syariah di Indonesia sehingga menambah keyakinan mahasiswa Islam dalam berinvestasi pada saham syariah serta mengajak masyarakat untuk aktif berkontribusi dalam investasi.

\section{B. KAJIAN LITERATUR}

1. Pasar Modal Syariah

Pasar modal adalah pasar yang memperjual belikan berbagai instrumen keuangan jangka panjang baik dalam bentuk hutang maupun dalam bentuk modal sendiri (Darmadji dan Fakhruddin, 2001:1). Adapun Pasar Modal Syariah adalah pasar modal yang dijalankan sesuai prinsip-prinsip syariat Islam (Sutedi, 2011:29). Perbedaan pasar modal syariah dengan konvensional menurut Sutedi (2011:52): Perbedaan pasar modal syariah dengan pasar modal konvensional.

\begin{tabular}{|l|l|l|l|}
\hline No. & Kriteria & \multicolumn{1}{|c|}{ Syariah } & \multicolumn{2}{|c|}{ Konvensional } \\
\hline 1 & Indeks & $\begin{array}{l}\text { Indeks Memasukkan } \\
\text { saham yang hanya } \\
\text { sesuai dengan } \\
\text { kriteria syariah }\end{array}$ & $\begin{array}{l}\text { Memasukkan seluruh } \\
\text { saham yang tercatat di } \\
\text { bursa dengan } \\
\text { mengabaikan aspek } \\
\text { halal dan haram }\end{array}$ \\
\hline 2 & $\begin{array}{l}\text { Instrumen } \\
\text { saham }\end{array}$ & $\begin{array}{l}\text { Obligasi syariah dan } \\
\text { reksadana syariah }\end{array}$ & $\begin{array}{l}\text { Surat-surat berharga } \\
\text { (Securities) seperti } \\
\text { saham, obligasi, dan }\end{array}$ \\
\hline
\end{tabular}




\begin{tabular}{|l|l|l|l|}
\hline & & & $\begin{array}{l}\text { instrumen turunannya, } \\
\text { (derivatif) opsi, right, } \\
\text { waran dan reksadana }\end{array}$ \\
\hline 3 & $\begin{array}{l}\text { Mekanisme } \\
\text { transaksi }\end{array}$ & $\begin{array}{l}\text { Tidak mengandung } \\
\text { transaksi ribawi, Tidak } \\
\text { ada transaksi yang } \\
\text { meragukan (gharar), } \\
\text { Saham perusahaan } \\
\text { yang } \\
\end{array}$ & $\begin{array}{l}\text { Transaksi } \\
\text { mengandung unsur } \\
\text { bunga, Terdapat } \\
\text { transaksi yang } \\
\text { mengandung unsur } \\
\text { ketidak jelasan, Saham } \\
\text { dibidang yang halal } \\
\text { perusahaan yang } \\
\text { diperjual belikan } \\
\text { dibidang yang belum } \\
\text { tentu halal }\end{array}$ \\
\hline
\end{tabular}

\section{Investasi Syariah}

Kata investasi merupakan kata adopsi dari bahasa Inggris, yaitu investment. Kata invest sebagai kata dasar dari investment memiliki arti menanam. Dalam kamus istilah Pasar Modal dan Keuangan kata investasi diartikan sebagai penanaman uang atau modal dalam suatu perusahaan atau proyek untuk tujuan memperoleh keuntungan. Investasi dapat diartikan sebagai pengeluaran yang ditujukan untuk meningkatkan atau mempertahankan stok barang modal (Aziz, 2010).

Kegiatan pembiayaan atau investasi keuangan menurut syariah pada prinsipnya adalah kegiatan yang dilakukan oleh pemilik harta (investor) terhadap pemilik usaha (emiten) untuk memberdayakan pemilik usaha dalam melakukan kegiatan usahanya yang pemilik harta (investor) berharap untuk memperoleh manfaat tertentu dengan didasarkan pada prinsip kehalalan dan keadilan (Sutedi, 2011). Investasi memiliki berbagai macam bentuk yang dapat digunakan. Namun dalam kajian ekonomi makro pasar modal, investasi dapat dilakukan dengan cara membeli saham di bursa efek melalui perusahaan sekuritas.

\section{Saham Syariah}

Saham (Stocks) adalah surat berharga yang bersifat kepemilikan dimana pemilik saham merupakan pemilik perusahaan, semakin besar saham yang dimilikinya semakin besar pula kekuasaannya pada perusahaan tersebut. Orang yang melakukan investasi untuk membeli saham disebut juga sebagai investor, tujuan utama para investor dalam membeli saham antara lain untuk memperoleh deviden, untuk memiliki atau menguasai perusahaan dan juga untuk berdagang memperoleh capital gain dimana investor akan menjual sahamnya kembali jika harga saham tersebit naik (Kasmir, 2014).

Sedangkan saham syariah merupakan saham-saham perusahaan yang dalam operasionalnya tidak bertentangan dengan syariat Islam, baik mengenai produk maupun manajemennya. Pengelompokan saham syariah berada dalam Jakarta Islamic Indeks (JII) di Bursa Efek Jakarta (BEJ) (Widodo, 2007). Saham syariah adalah saham yang tidak bertentangan dengan prinsip syariah 
dipasar modal, kriteria saham syariah sesuai dengan Peraturan Otoritas Jasa Keuangan (POJK) yang merujuk pada fatwa Majelis Ulama Indonesia (MUI) adalah sebagai berikut (IDX Syariah, 2018):

a. Emiten atau perusahaan tidak melakukan kegiatan antara lain: perjudian dan permainan yang tergolong judi, perdagangan yang dilarang menurut syariah, jasa keuangan ribawi seperti bank berbasis bunga dan perusahaan pembiayaan berbasis bunga, jual beli risiko yang mengandung unsur ketidakpastian (gharar) atau judi seperti asuransi konvensional, memproduksi, mendistribusikan dan memperdagangkan dan/atau menyediakan barang atau jasa haram melakukan transaksi yang mengandung unsur suap (Riswah).

b. Emiten memenuhi rasio-rasio keuangan sebagai berikut: total utang yang berbasis bunga dibandingkan dengan total aset tidak lebih dari $45 \%$ atau total pendapatan bunga dan pendapatan tidak halal lainnya dibandingkan dengan total pendapatan usaha dan pendapatan lain-lain tidak lebih dari $10 \%$.

Saham syariah yang saat ini diperdagangkan di Bursa Efek Indonesia (BEI) dikelompokkan ke dalam beberapa indeks saham yaitu Indeks Saham Syariah Indonesia (ISSI) yaitu berisi seluruh saham syariah yang tercatat di BEI dan masuk dalam Daftar Efek Syariah (DES) yang diterbitkan oleh OJK, kemudian terdapat pula Jakarta Islamic Index (JII) yaitu kelompok saham syariah yang terdiri dari 30 saham syariah paling likuid yang tercatat di BEI dan yang terakhir adalah Jakarta Islamic Index 70 (JII70) yaitu kelompok saham syariah yang likuid yang tercatat di BEI (Purboyo et al., 2019).

Menurut Peraturan Nomor II.K.1 tentang Kriteria dan Penerbitan Daftar Efek Syariah, kriteria saham syariah adalah tidak melakukan kegiatan usaha sebagai berikut;

a. Perjudian dan permainan yang tergolong judi

b. Perdagangan yang dilarang menurut syariat Islam

c. Jasa keuangan ribawiJual beli resiko yang mengandung unsur ketidakpastian (gharar) dan/atau judi (maisir)

d. Memproduksi, mendistribusikan, memperdagangkan dan/atau menyediakan barang dan jasa yang haram zatnya dan haram bukan zatnya serta yang merusak moral atau mudharat yang telah ditetapkan DSN-MUI.

e. Melakukan transaksi yang mengandung unsur suap.

Dengan demikian investasi saham syariah merupakan suatu aktivitas yang berkaitan dengan penarikan sumber dana yang dimasukkan kedalam sebuah share (saham) yang tidak bertentangan dengan prinsip-prinsip syariat Islam.

4. Landasan Hukum Saham Syariah

Hukum mengenai saham syariah belum ada secara jelas dan pasti di dalam Alquran dan hadits. Maka para ulama dan fuqaha kontemporer berusaha untuk menemukan rumusan kesimpulan hukum tersendiri dengan cara ijtihad mengenai saham ini. Para fuqaha kontemporer berselisih pendapat dalam memperlakukan saham. Sebagian membolehkan transaksi jual beli saham dan ada juga yang tidak membolehkan. Menurut Wahbah al Zuhaili, bermuamalah dengan (melakukan kegiatan transaksi atas) saham hukumnya boleh, karena 
pemilik saham adalah mitra dalam perseroan sesuai dengan saham yang dimilikinya. Pendapat para ulama yang memperbolehkan jual beli saham serta pengalihan kepemilikan porsi suatu surat berharga berdasarkan pada ketentuan bahwa semua itu disepakati dan diizinkan oleh pemilik porsi lain dari suatu surat berharga. Keputusan Muktamar ke-7 Majma' Fiqh Islami tahun 1992 di Jeddah juga menyatakan bahwa boleh menjual dan menjaminkan saham dengan tetap memperhatikan peraturan yang berlaku pada perseroan (Rivai, dkk, 2014: 247). Fatwa Dewan Syari'ah Nasional Indonesia, dalam Fatwa DSN-MUI No. 40/DSN-MUI/2003, telah merumuskan bahwa jual beli saham adalah boleh dilakukan (Choirunnisak, 2019).

5. Perkembangan Saham Syariah di Indonesia

Tidak semua jenis saham diperbolehkan untuk diperdagangkan dalam pasar modal syariah, jenis saham yang dilarang adalah preferred stock (saham istimewa). Terdapat perbedaan besar antara saham biasa (common stock) dan saham istimewa (preferred stock) yang mendasari pelarangan untuk diperdagangkan di pasar modal syariah yaitu :

Pada saham istimewa jika perusahaan mengalami kebangkrutan (dilikuidasi) maka pemegangnya mendapat prioritas pertama untuk memperoleh pembayaran dibandingkan pemegang saham biasa, hal ini tentu bertentangan dengan prinsip keadilan sebagai salah satu prinsip Islam. Dalam hal pembagian deviden perusahaan, tidak ada jaminan kepastian besarnya deviden bagi pemegang saham biasa, deviden dapat berfluktuasi tergantung dari kemampuan perusahaan menghasilkan laba, sementara untuk pemegang saham istimewa ada jaminan kepastian untuk memperoleh deviden tetap tanpa melihat kondisi perusahaan. Adanya keuntungan tetap bagi saham istimewa dapat dikategorikan riba yang sangat dilarang dalam Islam .

Perkembangan perdagangan saham syariah ditunjukkan oleh nilai Indeks Saham Syariah Indonesia (ISSI). ISSI dibutuhkan untuk menggambarkan kinerja seluruh saham syariah yang terdaftar di Bursa Efek Indonesia (BEI), sedangkan dalam Jakarta Islamic Index (JII) hanya diwakili oleh 30 emiten yang penentuannya melibatkan Dewan Pengawas PT. Danareksa Investment Management. Perkembangan ISSI dan JII dapat ditunjukkan dalam tabel sebagai berikut (OJK, 2020); 


\section{SAHAM SYARIAH}

\section{KAPITALISASI PASAR BURSA EFEK INDONESIA}

(Rp Miliar)

\begin{tabular}{|c|c|c|c|c|}
\hline & TAHUW & LARARTA ISLAMVIC INDEX & $\begin{array}{c}\text { WWDEKS SAHEAG SYARYAH } \\
\text { INDONESEA }\end{array}$ & $\begin{array}{l}\text { LAKARTA ISLAMTIC } \\
\text { LNDEX } 70\end{array}$ \\
\hline 2000 & & $74-268,92$ & - & - \\
\hline $200 t$ & & $87.731,59$ & - & - \\
\hline 2002 & & $92.070,49$ & - & - \\
\hline 2003 & & $177 \cdot 781,89$ & - & - \\
\hline 2004 & & 263.863 .34 & - & - \\
\hline 2005 & & $395,649,8.4$ & - & - \\
\hline 2006 & & 620.165 .31 & - & - \\
\hline 2007 & & $1.105 .897,25$ & - & - \\
\hline 2008 & & 428.525 .74 & - & - \\
\hline 2009 & & $937.919,08$ & - & - \\
\hline 2010 & & $1.134 .632,00$ & - & - \\
\hline 2011 & & $1.414-983,81$ & $2.968 .091,37$ & - \\
\hline 2012 & & $1.672 .004,23$ & 2.451 .334 .37 & - \\
\hline 2013 & & 2.672 .099 .91 & 2.557 .8 .46 .77 & - \\
\hline 2014 & & $1.944-531,70$ & $2.946 .892,79$ & - \\
\hline 2015 & & $1.737 .290,98$ & 2.600 .850 .72 & - \\
\hline 2016 & & 2.035 .189 .92 & $3.170 .056,08$ & - \\
\hline 2017 & & $2.288 .015,67$ & $3.704-543,09$ & - \\
\hline 2018 & & 2.239 .507 .78 & $3.666 .688,31$ & 2715.851 .74 \\
\hline 2019 & & $2.318 .565,69$ & $3-744-816,32$ & $2.800 .001,49$ \\
\hline 2020 & $\begin{array}{l}\text { Januari } \\
\text { Februari }\end{array}$ & $\begin{array}{r}2.134-960,15 \\
1.876,573,15\end{array}$ & $\begin{array}{l}3.46 .4-489.36 \\
3.139 .077 .45\end{array}$ & $\begin{array}{l}2.574 .301,02 \\
2.283 .779 .96\end{array}$ \\
\hline
\end{tabular}

1 STATISTIK PASAR MODAL SYARIAH

Direktorat Pasar Modal Syariah - Otoritas Josa Kewangan

Kapitalisasi pasar merupakan nilai perusahaan yang dihitung dari jumlah seluruh saham perusahaan beredar dikalikan dengan harga pasar saham, dengan demikian semakin mahal harga saham maka semakin tinggi nilai kapitalisasinya. Jika dilihat dari nilai kapitalisasi, saham-saham syariah menunjukkan peningkatan yang konsisten, hal ini mengindikasikan kondisi makro ekonomi yang stabil yang dapat memberikan harapan yang baik bagi peningkatan kinerja perusahaan. Dilihat dari fungsi ekonomi, meningkatnya nilai kapitalisasi saham syariah menunjukkan keberhasilan pasar modal syariah sebagai pengumpul sumber dana alternatif bagi investasi perusahaan yang berlandaskan prinsip syariah, disamping itu menunjukkan meningkatnya kesadaran masyarakat khususnya umat Islam, yang memiliki kelebihan dana, untuk memilih jenis investasi keuangan yang halal.

Jika dilihat dari jumlah saham beredar, perkembangan saham syariah dapat dilihat dalam grafik berikut : Grafik Perkembangan Jumlah Saham Syariah (OJK, 2020). 


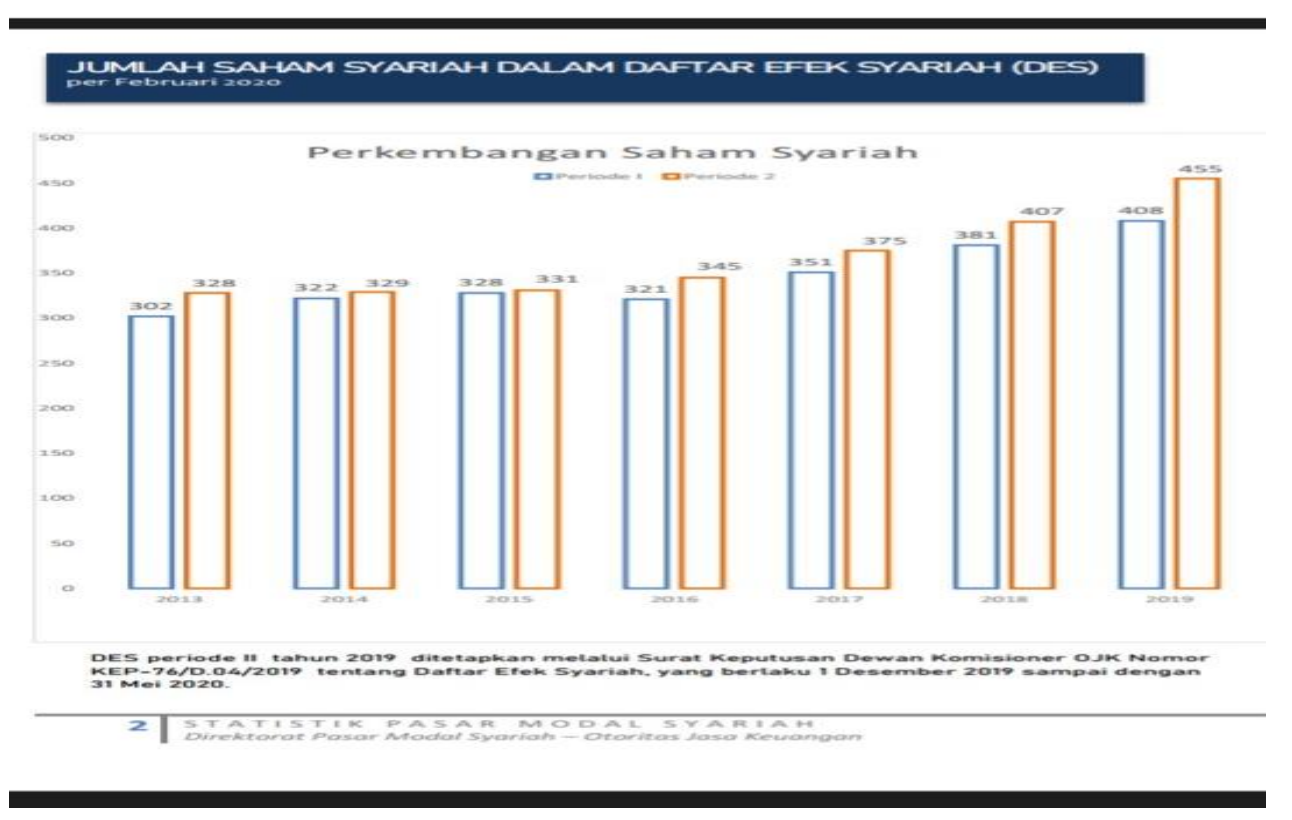

Grafik di atas menunjukkan bahwa jumlah saham syariah yang tercatat di bursa dari tahun ke tahun menunjukkan peningkatan, hal ini menggambarkan meningkatnya kesadaran perusahaan akan potensi bisnis dengan prinsip syariah yang berkeadilan dan bersih dari unsur-unsur riba. Di sisi lain dengan mengeluarkan saham syariah, perusahaan dapat mengambil keuntungan dari fleksibilitas perdagangan saham syariah, saham syariah dapat diperdagangkan kepada muslim dan non muslim di bursa konvensional maupun syariah sementara saham konvensional hanya dapat diperdagangkan di bursa konvensional saja. Fleksibilitas ini dapat menjadi potensi yang menguntungkan karena terbukanya kesempatan untuk mengumpulkan dana lebih besar dari para investor.

\section{METODE PENELITIAN}

1. Pendekatan penelitian

Rancangan penelitian ini menggunakan pendekatan kualitatif. Pendekatan kualitatif digunakan untuk melakukan kajian implementasi, daya dukung lapangan, dan observasi proses pengembangan. Penelitian kualitatif menurut Zainal Arifin (2011:140) adalah "suatu proses penelitian yang dilakukan secara wajar dan natural sesuai dengan kondisi objektif dilapangan tanpa adanya manipulasi, serta jenis data yang dikumpulkan terutama data kualitatif".

Metode yang digunakan dalam penelitian ini adalah metode deskriptif analitis. Metode penelitian ini berdasarkan pada pemecahan masalah berdasarkan fakta-fakta atau kenyataan pada saat sekarang dan memusatkan pada masalah yang terjadi pada saat penelitian dilaksanakan. Selaras dengan yang dikemukakan oleh Sugiyono (2012:29) bahwa "metode deskriptif adalah metode yang digunakan untuk mengambarkan dan menganalisis suatu hasil penelitian".

2. Populasi dan sampel

Populasi dalam penelitian ini adalah para investor saham syariah di Indonesia. Sampel yang digunakan dalam penelitian ini adalah hasil dari wawancara 10 responden melalui google forms. 


\section{Sumber data}

Sumber data yang digunakan dalam penelitian ini adalah sebagai berikut;

a. Data primer yang ada dalam penelitian ini diperoleh dari hasil wawancara yang diberikan kepada 10 responden melalui google forms.

b. Data sekunder yang ada dalam penelitian ini diperoleh dengan mencari informasi dari beberapa literatur dan artikel yang berkaitan.

4. Teknik pengumpulan data

a. Kuesioner terbuka

Kuesioner adalah teknik pengumpulan data yang dilakukan dengan cara memberi seperangkat pertanyaan tertulis kepada responden untuk dijawab. Penyebaran kuesioner dilakukan sebagai alat untuk mengukur tanggapan dari responden dan memudahkan peneliti dalam pengukuran data. Dalam penelitian ini, kuesioner dibagikan melalui google forms yang terdiri dari 10 pertanyaan kepada 10 responden investor saham syariah.

b. Studi pustaka

Penelitian kepustakaan atau studi pustaka merupakan kegiatan dengan metode pengumpulan data pustaka, membaca dan mencatat serta mengolah bahan penelitian. Menurut Mestika Zed (Zed, 2008), ada beberapa alasan mengapa penelitian menggunakan studi pustaka dan langkah-langkah untuk melakukan penelitian kepustakaan yaitu; penelitian ini hanya bisa dijawab dengan studi pustaka; sebagai tahap tersendiri yaitu studi pendahuluan untuk memahami lebih dalam gejala baru yang telah berkembang di lapangan atau yang ada di masyarakat; data pustaka tetap handal untuk menjawab persoalan penelitian: misalnya riset yang dilakukan orang lain dan berasal dari laporan-laporan resmi (Selasi, 2019)

\section{HASIL DAN PEMBAHASAN}

Hasil dari study pustaka dan wawancara melalui google form yang disebarkan kepada para investor saham syariah menunjukkan bahwa banyak keuntungan yang yang mendasari para investor berinvestasi saham syariah, keuntungan tersebut adalah :

\section{Investasi saham syariah sesuai dengan ajaran agama Islam}

MUI (Majelis Ulama Indonesia) telah menjamin kehalalan dari saham- saham syariah yang tercatat di Pasar modal dan pasti telah teruji Pasar modal beserta seluruh mekanisme kegiatannya terutama mengenai emiten, jenis Efek yang diperdagangkan dan mekanisme perdagangannya yang dipandang telah sesuai dengan Syariah.

Ada dua jenis saham syariah yang diakui di pasar modal Indonesia. Pertama, saham yang dinyatakan memenuhi kriteria seleksi saham syariah berdasarkan peraturan OJK Nomor 35/POJK.04/2017 tentang Kriteria dan Penerbitan Daftar Efek Syariah, kedua adalah saham yang dicatatkan sebagai saham syariah oleh emiten atau perusahan publik syariah berdasarkan peraturan OJK no. 17/POJK.04/2015.

Semua saham syariah yang terdapat di pasar modal syariah Indonesia, baik yang tercatat di BEI maupun tidak, dimasukkan ke dalam Daftar Efek Syariah (DES) yang diterbitkan oleh OJK secara berkala, setiap bulan Mei dan November. Saat ini, kriteria seleksi saham syariah oleh OJK adalah sebagai berikut;

a. Emiten tidak melakukan kegiatan usaha sebagai berikut: 
1) Perjudian dan permainan yang tergolong judi;

2) perdagangan yang dilarang menurut syariah, antara lain:

a) perdagangan yang tidak disertai dengan penyerahan barang/jasa;

b) perdagangan dengan penawaran/permintaan palsu;

3) jasa keuangan ribawi, antara lain:

a) bank berbasis bunga;

b) perusahaan pembiayaan berbasis bunga;

4) jual beli risiko yang mengandung unsur ketidakpastian (gharar) dan/atau judi (maisir), antara lain asuransi konvensional;

5) memproduksi, mendistribusikan, memperdagangkan, dan/atau menyediakan antara lain:

a) barang atau jasa haram zatnya (haram li-dzatihi);

b) barang atau jasa haram bukan karena zatnya (haram lighairihi) yang ditetapkan oleh DSN MUI;

c) barang atau jasa yang merusak moral dan/atau bersifat mudarat;

6) melakukan transaksi yang mengandung unsur suap (risywah); dan

b. Emiten memenuhi rasio-rasio keuangan sebagai berikut:

1) total utang yang berbasis bunga dibandingkan dengan total aset tidak lebih dari $45 \%$ (empat puluh lima per seratus); atau

2) total pendapatan bunga dan pendapatan tidak halal lainnya dibandingkan dengan total pendapatan usaha (revenue) dan pendapatanlain-lain tidak lebih dari $10 \%$ (sepuluh per seratus);

2. Capital gain

Selain saham konvensional, dalam saham syariah juga terdapat keuntungan capital gain. Keuntungan yang didapat ketika saham bertumbuh dan mencapai target harga, maka kelebihan atau keuntungan yang didapatkan ketika penjualan itulah yang dimaksud dengan capitail gain.

3. Dividen

Dividen merupakan pendapatan yang diperoleh secara periodik dari investasi saham. Jika perusahaan yang menerbitkan saham syariah mendapatkan laba, maka setiap investor saham akan menerima pembagian laba (dividen). Dividen baru akan dibagikan setelah mendapatkan persetujuan dari pemegang saham dalam (RUPS).

\section{Terdapat saham likuid dan masuk Indeks LQ45}

Ada beberapa saham syariah yang masuk dalam Indeks LQ45. Indeks LQ45 menggunakan 45 emiten yang dipilih berdasarkan pertimbangan likuiditas dan kapitalisasi pasar, dengan kriteria-kriteria yang telah ditentukan. Dari sini bisa dilihat bahwa saham syariah termasuk saham yang likuid dan layak dijadikan sarana investasi.

\section{Terdapat saham Blue-chip}

Selain saham syariah dalam kategori likuid, terdapat pula saham syariah yang tergolong dengan saham blue chip (saham kapitalisasi besar). Saham blue-chip ini minim dengan risiko penurunan harga yang terlalurendah, sehingga lebih aman untuk dijadikan pilihan investasi.

\section{Kepemilikan perusahaan}

Saham merupakan bagian dari modal perusahaan (equity). Artinya modal sebuah perusahaan terbagi dalam saham. Investor saham otomatis ikut berkontribusi dalam memberi modal ke sebuah perusahaan dan itu berarti ikut menjadi pemilik 
perusahaan. Semakin besar persentase kepemilikan saham, maka hak dan kewajiban seseorang terhadap perusahaan tersebut juga semakin besar.

\section{SIMPULAN}

Berdasarkan hasil penelitian dan analisis data, dapat ditarik kesimpulan bahwa keuntungan yang didapatkan dalam berinvestasi syaraih adalah investasi saham syariah sesuai dengan ajaran agama Islam, capital gain, dividen, terdapat saham likuid dan masuk Indeks LQ45, terdapat saham Blue-chip dan kepemilikan perusahaan.

\section{DAFTAR PUSTAKA}

Aziz, A. (2010). Manajemen Investasi Syariah. Alfabeta.

Choirunnisak. (2019). Saham Syariah; Teori Dan Implementasi. ISLAMIC BANKING, Volume 4 Nomor 2 Februari. 71.

Fahmi, I. (2012). Pengantar Pasar Modal (Panduan Bagi Para Akademis dan Praktisi Bisnis dalam Memahami Pasar Modal Indonesia). Alfabeta.

Faqih, A. (2018). Praktik Jual Beli Saham Syari'ah Perspektif Hukum Islam. IQTISAD, 5(Juni), 43-74.

Febrianti, S. (2018). Analisis Perbandingan Kinerja Indeks Saham Syariah dengan Indeks Saham Konvensional Periode 2015-2017. Ilmu Manajemen.

Hermuningsih, S. (2012). Pengantar Pasar Modal Indonesia. UPP STIM YKPN.

Kasanah, H. R., \& Worokinasih, S. (2018). Analisis Perbandingan Return Dan Risk Saham Syariah Dengan Saham Konvensional.

Administrasi Bisnis, 58(2), 46-55.

Kasmir. (2014). Analisis Laporan Keuangan (Cetakan Ke). PT Raja Grafindo Persada.

Manan, A. (2012). Hukum Ekonomi Syariah: Dalam Perspektif Kewenangan Peradilan Agama (Cet. 1). Prenada Media Group.

Nurlita, A. (2014). Investasi Di Pasar Modal Syariah Dalam Kajian Islam. Penelitian Sosial Keagamaan, 17(1), 1-20.

OJK. (2020). Statistik Pasar Modal Syariah. Direktorat Pasar Modal Syariah.

Purboyo, Zulfikar, R., \& Wicaksono, T. (2019). Pengaruh Aktiivitas Galeri Investasi, Modal Minimal Investasi, Persepsi Resiko dan Persepsi Return Terhadap Minat Investasi Saham Syariah. Wawasan Manajemen, 7, 136- 150.

Rivai, V., \& Bukhari, A. (2013). Islamic Economics (Ekonomi Syariah Bukan Opsi, Tetapi Solusi!). Bumi Aksara.

Selasi, D. (2019). Implementasi Ekonomi Syariah Pada Perkembangan Investasi Saham Syariah Di Era Distrupsi. Jurnal Inklusif, Vol: 4 No: 1 June. 17-18.

Sutedi, A. (2011). Pasar Modal Syariah. Sinar Grafika.

Tavinayati, \& Qamariyanti, Y. (2009). Hukum Pasar Modal di Indonesia. Sinar Grafika.

Widodo, S. (2007). Analisis Pengaruh Rasio Aktivitas, Rasio Profitabilitas, Dan Rasio Pasar, Terhadap Return Saham Syariah Dalam Kelompok Jakarta Islamic Index (Jii) Tahun 2003 - 2005. Program Magister Manajemen Universitas Diponegoro, 76.

Zed, M. (2008). Metode Penelitian Kepustakaan. Yayasan Obor Indonesia. 